\title{
MACROPRUDENTIAL THEORY: ADVANCES AND CHALLENGES
}

Henrique s. Basso and James costain

Documentos ocasionales N. 1604

BANCOD ESPANA

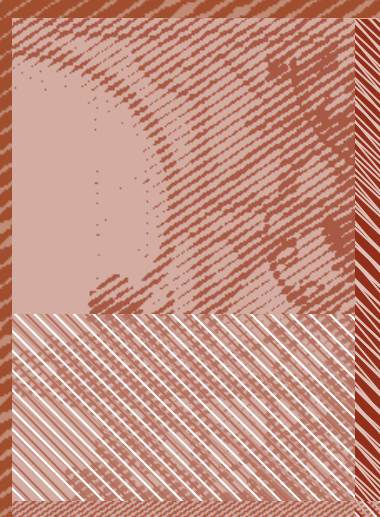

Eurosistema 
MACROPRUDENTIAL THEORY: ADVANCES AND CHALLENGES 
MACROPRUDENTIAL THEORY: ADVANCES AND CHALLENGES

Henrique S. Basso and James Costain

BANCO DE ESPAÑA

Documentos Ocasionales. N. ${ }^{\circ} 1604$ 
The Occasional Paper Series seeks to disseminate work conducted at the Banco de España, in the performance of its functions, that may be of general interest.

The opinions and analyses in the Occasional Paper Series are the responsibility of the authors and, therefore, do not necessarily coincide with those of the Banco de España or the Eurosystem.

The Banco de España disseminates its main reports and most of its publications via the INTERNET at the following website: http://www.bde.es.

Reproduction for educational and non-commercial purposes is permitted provided that the source is acknowledged.

(C) BANCO DE ESPAÑA, Madrid, 2016

ISSN: 1696-2230 (on line) 


\section{Abstract}

This note discusses recent theoretical work analyzing the causes of financial instability, its consequences for the macroeconomy, and thus the potential role for macroprudential policy. After discussing how information asymmetries and strategic complementarities can cause balance sheet losses to propagate through the financial system and over time, we discuss the role of the major classes of macroprudential instruments in preventing instability ex ante and containing it ex post. We conclude with a discussion of current challenges for macroeconomic modeling and for the design of regulation and policy.

Keywords: banks, financial stability, financial regulation, macroeconomic policy.

JEL classification: E44, E6, G2, G28. 


\section{Resumen}

Este documento ocasional resume los avances recientes en el análisis teórico de las causas de la inestabilidad financiera, de sus consecuencias macroeconómicas, y sus implicaciones acerca del posible papel de la política macroprudencial. En primer lugar, se analiza cómo se propagan las perturbaciones financieras a través del sistema financiero y a lo largo del tiempo, debido a las asimetrías de información y a las complementariedades estratégicas. Luego, se comenta el papel de cada clase de instrumentos macroprudenciales para evitar la inestabilidad financiera ex ante y para contrarrestarla ex post. Se concluye con una discusión de los retos actuales para la modelización macroeconómica y para el diseño de la regulación y de la política asociados con temas macroprudenciales.

Palabras clave: bancos, estabilidad financiera, regulación financiera, política macroeconómica.

Códigos JEL: E44, E6, G2, G28. 


\section{Introduction}

The financial system trades payoffs across hypothetical states of the world, and across time. Therefore it is subject to certain inherent instabilities, in which the valuation of possible future outcomes makes equilibrium prices depend on the optimism or pessimism of investors. Uncertainty about hypothetical futures also makes finance and banking especially vulnerable to the corporate governance problems that are caused by asymmetric information and limited liability in all sectors of the economy.

Events of the past decade have forced economists to face up to the risks posed by financial instability, so research on how policy should address financial instabilities and distortions has proliferated. This brief note provides a selective review of recent work, with the aim of identifying priorities for ongoing research. ${ }^{1}$ We start by recalling the role of microprudential policy, because many of the potential problems and policy instruments under discussion in the literature about macroprudential policy are closely related to issues already familiar from the microprudential context. Next, the note discussess how financial vulnerabilities may propagate across banks at a given point in time, and through time over the course of the business cycle. This macroeconomic perspective gives scope to ask which channels and instruments of macroprudential policy can address the propagation of financial vulnerabilities. The final section identifies major research challenges, and concludes.

\section{Banking and microprudential regulation}

By aggregating risks (acquiring loans that pay out differently in different states of the world, in exchange for largely riskless cash that pays off in all states of the world) the banking system transforms numerous risky loans into a few safer assets, thus promoting investment and growth. In this credit provision function, banks must monitor the creditworthiness of the investments of households, entrepreneurs, and firms. As banks specialize in a monitoring role, they acquire superior information to that held by their depositors, which implies that the equilibrium of the banking system may be distorted by asymmetric information problems such as moral hazard and adverse selection.

On the other hand, by aggregating individual liquidity needs, a bank increases the predictability of its deposit outflows, permitting it to economize on reserves. In its liquidity provision role, the banking system safeguards depositors' funds while providing immediate access when those depositors need to spend. Thus, banks' long maturity loans are made on the basis of very short maturity funding, so maturity mismatch is inherent to the role of banking in the economy. ${ }^{2}$ Kashyap, Rajan, and Stein (2002) point out that the twin roles of the banking system (trade across time and trade across states of the world) are

\footnotetext{
${ }^{1}$ Hence, this note complements that of Mencía and Saurina (2016), who discuss indicators and instruments for macroprudential policy, especially those in use at the Banco de España. Here we provide an overview of recent theoretical work describing the market failures that make macroprudential policy necessary and determine its principal objectives.

${ }^{2}$ Without claiming that mismatch can be eliminated entirely, Goodhart and Perotti (2015) argue that contemporary banking's emphasis on long-term loan provision stretches mismatch to inefficient levels, compared with the discounting of trade credit that was the mainstay of the banking business through the first half of the twentieth century.
} 
naturally complements: both liquidity provision and credit provision, whether as credit lines or as loans, require the bank to maintain a stock of liquid reserves. Therefore there is an efficiency motive for a single class of institutions to undertake both tasks.

Given these two roles, banks are subject to two main sources of risk. First, due to corporate governance problems, banks may fail to adequately minimize the risks in their investment portfolios. As banks intermediate funds from savers to investors, their aggregation of risky assets represents an important insurance mechanism that insulates savers from idiosyncratic investment risks. The composition and relative size of a bank's investments, relative to its funding, determines the riskiness of its balance sheet, summarized for example by its leverage ratio (the ratio of risky assets to the bank's own equity). While leverage is an intrinsic aspect of intermediation, it magnifies risk in the bank's portfolio, and may be suboptimally high. Admati, DeMarzo, Hellwig, and Pfleiderer (2013b) explain how shareholder-creditor conflict may build up excess leverage over time: once debt is in place, shareholders will consistently prefer to increase leverage by accumulating further assets without increasing bank equity, even when lower leverage would increase the total value of the bank. This leverage rachet effect occurs because the dilution costs of recapitalization are paid by shareholders only, while lower leverage increases the expected payoff for all stakeholders, including creditors. Excessive risk taking may also be driven by banks' incentive to concentrate their portfolios on riskier assets, which depositors may fail to observe due to their informational disadvantage. This risk shifting effect results from the fact that shareholders benefit from higher returns but are protected from increased insolvency costs by their limited liability (see Jensen and Meckling (1976) and Bolton, Mehran, and Shapiro (2010)). Moreover, the incentive to shift risks is increased for highly leveraged entities, so the leverage ratchet and risk shifting effects reinforce each other, pushing banks further from the socially optimal degree of risk taking. These governance problems between shareholders and creditors may also be reinforced by governance problems between managers and shareholders, since monitoring effort is difficult to observe (Holmstrom and Tirole (1997)).

A second risk is that, by providing liquidity insurance, banks expose themselves to the danger of runs. Diamond and Dybvig (1983) argue that the occurrence of a run is a particularly severe form of inefficiency, since the bank's balance sheet is also compatible with a different equilibrium in which no run occurs. Both the optimistic outcome, in which depositors keep their money in the bank(s), and the panic outcome, in which one or more banks fail, are rational equilibria under laissez faire; individual depositors can do nothing, in principle, to shepherd the market from one equilibrium outcome to another. ${ }^{3}$ While bank runs were once seen as a phenomenon related to retail banking, the recent financial crisis saw banks such as Bear Sterns suffering panics in which short-term wholesale funding was suddenly withdrawn. Creditors may gain de facto seniority if they hold assets that mature first relative to the other liabilities of borrowers, so that when there is uncertainty about default probabilities, both borrowers and new creditors have an incentive to shorten maturity at the expense of current creditors (Brunnermeier and Oehmke (2013) call this

\footnotetext{
${ }^{3} \mathrm{~A}$ large actor, such as the central bank, can influence expectations in a way that selects the Pareto dominant equilibrium. Therefore Diamond and Dybvig (1983) argue that a regime of deposit insurance may be welfare improving. On the other hand, the presence of deposit insurance diminishes the monitoring incentives of depositors and banks themselves, so that the lender of last resort function goes hand in hand with a supervisory function for the central bank.
} 
the maturity rat race), implying excessive rollover risk. On the other hand, Calomiris and Kahn (1991) argued that short-term funding (demandable debt) can be an important discipline device to ensure that banks have an adequate incentive to monitor. In their model, a large wholesale funder holding demandable debt internalizes monitoring incentives, disciplining the bank, which allows small depositors to free ride in the monitoring decision. But while this might provide an efficient solution to the monitoring of a single bank, it still leaves the economy open to panics at the aggregate level. Moreover, Huang and Ratnovski (2011) reverse the conclusion of Calomiris and Kahn (1991), showing that if noisy public signals are available, then short-term wholesale funding may instead decrease monitoring incentives, triggering inefficient liquidations and increasing the frequency of bank runs.

Faced with the likelihood of excessive risk in the banking system, policy makers intervene by supervising banks and by setting prudential policies at the micro level. Capital requirements, one of their key policy instruments, serve to internalize bank losses, mitigating problems of maturity mismatch, excessive risk, and leverage at the bank level. A common argument for reducing these requirements is that since equity is riskier than debt, it is a more expensive form of funding, so that requiring higher equity holdings leads to higher loan rates and lower credit. However, under the Modigliani-Miller conditions (Modigliani and Miller (1958)), this is untrue: even if equity is more expensive than debt, higher equity ratios decrease the probability of default, leaving the overall cost of funding unchanged. Even when the Modigliani-Miller conditions are violated (for example, if holding debt has tax benefits, or if there is a "money" premium on short-term debt that can be used as a transaction medium), the increase in the interest rate on loans due to capital requirements is unlikely to be large (Hanson, Kashyap, and Stein (2011), see also Admati, DeMarzo, Hellwig, and Pfleiderer (2013a)). Recognizing that capital requirements may be insufficient to correct all possible biases - not least because managers may fail to fully represent the interests of shareholders - leverage and liquidity ratios have also been added recently as regulatory tools, aimed directly at correcting excessive leverage and excessive maturity mismatch, respectively. ${ }^{4}$

\section{Macroeconomic perspective}

The need for a macroeconomic approach to prudential financial regulation arises from a variety of externalities that may spread the vulnerabilities of individual institutions across the whole financial system. When an individual depositor withdraws her savings from a bank because she expects other clients to withdraw their deposits too, this is an example of a strategic complementarity - an externality in which an action chosen by any agent strengthens the incentives of other agents act in the same way. In the financial system, strategic complementarities can produce multiple equilibria (banking panics) at the level of a single bank, but they may also feed back across the whole banking system and produce additional externalities on the rest of the economy. Market-wide spillovers imply that the risk in the financial system is not just the sum of individual risks, but is endogenous, born out of the collective behaviour of financial entities. Risks propagate both through the cross-section of banks ("structural" propagation) and over time ("cyclical"propagation).

\footnotetext{
${ }^{4}$ See De Nicolo, Gamba, and Lucchetta (2012) and Goodhart, Kashyap, Tsomocos, and Vardoulakis (2012) for general equilibrium frameworks that address the effects of each of these tools on the banking sector.
} 


\section{Strategic complementarities in the cross-section}

Credit crunches and fire sales

The interaction between financial frictions and the business cycle was first explored by looking at the role of collateral and its valuation. Bernanke, Gertler, and Gilchrist (1999) explored a costly verification framework to show how binding collateral constraints could lower economic activity and amplify economic fluctuations. Lower cash reserves increase moral hazard problems within the firm, leading to a lower level of output, and thus to lower income for other firms. Although the initial focus was on firm collateral, the same framework was later applied to explore credit crunches generated through banking balance sheets (Gertler and Kiyotaki (2010)).

Collateral feedback may go through the quantity of liquid resources available in the economy, as financial intermediaries are forced to sell assets at times when potential buyers lack sufficient liquidity (cash-in-the-market is low - see Allen and Gale (1994)). But the feedbacks implied by this mechanism will go through prices as well as quantities (Kiyotaki and Moore (1997)); lower prices caused by sales of distressed firms not only harm the current seller, but also all other holders of similar assets. Balance sheet losses then spread across the system, forcing other banks to sell too, lowering prices further and bringing new sellers to the market. Thus, individual bank problems spill over to the rest of the system through this pecuniary externality. This is inefficient, since market participants do not internalize the effect of their asset sales on the prices faced by other agents, so each participant chooses a lower liquidity buffer, ex ante, than the socially optimal level.

While in the first instance fire sales affect the prices of assets in distress, they may also spill over to other asset types. Manconi, Massa, and Yasuda (2012) show that during the recent financial crisis, mutual funds needing liquidity chose to sell assets other than securitized bonds, since these were seen as "toxic", so fire sales spilled over from securitized to corporate bonds, and corporate spreads increased. Fire sales can also be amplified through their interactions with funding and risk management considerations. Garleanu and Pedersen (2007) argue that since banks restrict balance sheet holdings in order to abide by a liquidity-adjusted value at risk (LVaR) constraint, tighter risk management may lead to a general reduction in asset holding. As a result, all participants face longer expected selling times, implying higher risk over the now longer holding period, which further tightens risk management, producing added downward pressure on prices. Brunnermeier and Pedersen (2009) focus on the role of funding on triggering pecuniary externalities. Financial institutions use asset holdings as collateral to fund their balance sheet holdings. A lower value of the underlying asset used as collateral reduces funding capacity, generating a constraint on asset holdings, an increase in sell orders and lower asset prices, which further decreases funding capacity as funding margins increase.

\section{Flight to quality and liquidity; risk shifting}

Strategic complementarities in the overall level of activity may also be reinforced by feedbacks in the type of investment undertaken. A credit crunch may feature a shift out 
of riskier (more productive) investments, and into safer or more liquid (less productive) assets. These could include shifts out of real investment and into government bonds, or shifts from one class of real assets to another (for example, from small to large firms).

The scope for these ex post shifts out of risk may be increased by inefficiently high risk taking ex ante. Limited liability may make riskier assets attractive to banks, due to their potential upside gain. These riskier assets may have higher (Allen and Gale (2004)) or lower (Repullo (2004)) expected payoffs ex ante; in either case, shifting into riskier assets will be especially attractive when expected profits are low, which means that greater banking competition may increase risk shifting. Greater risk-taking ex ante means that a crisis, if it occurs, will be more severe. In this way, risk shifting externalities may reinforce other types of strategic complementarities discussed earlier. In particular, they may make the economy vulnerable to a flight to quality when pessimism sets in.

\section{Asset commonalities}

Strategic complementarities may also be driven by investors' asset allocation decisions, if the payoff to a certain asset class increases with the fraction of other agents choosing the same investment strategy. Acharya (2009) presents a framework where systemic risk results from endogenously chosen correlation of returns on assets held by banks. The limited liability of banks, combined with a negative externality of one bank's failure on the health of other banks, gives rise to a systemic risk-shifting incentive where all banks undertake correlated investments, thereby increasing economy-wide aggregate risk. Wagner (2010) and Allen, Babus, and Carletti (2012) also explore mechanisms where diversification is privately beneficial but increases the likelihood of systemic events as portfolios become more similar.

Similarities of portfolio allocation across financial intermediaries may also result from the prospect of government bailouts. Anticipating that simultaneous bank failures trigger a bailout (preventing a systemic event) banks may find it optimal to correlate risk taking, so that any bank failure is also a system failure (Farhi and Tirole (2012)). Peer benchmarking may also generate externalities across banks, leading to asset commonality, since poor performance may overlooked by the market if many other banks suffer similar losses, while losing alone harms the banker's reputation (see Rajan (1994)).

\section{Modes of propagation through the financial system}

The discussions above have implicitly assumed that the decisions of individual banks and firms are driven by aggregate prices and quantities of risky and liquid assets. But feedbacks in the interbank market may instead have a network structure, in which a bank failure spills over to the rest of the system primarily through domino effects on other banks with which it interacts closely. These domino effects may result from direct linkages or from cross trading (counterparty effects). Allen and Gale (2000) analyze how contagion acts under different network structures, and show that incomplete networks are more prone to contagion than complete structures. Also, greater connectivity typically reduces the likelihood of widespread default as it increases the ability of a network to absorb shocks. However, when large shocks occur, their effects are amplified, since more counterparties are affected. Rochet and Tirole (1996) also analyse the risk of systemic crises due to 
interconnectedness in the interbank market, making clear that systemically importance depends on connections, as well as size. Information contagion is another possible form of propagation: any bank failure may cast doubt about the solvency of other market participants that have similar asset and liability structures (Brunnermeier, Goodhart, Persaud, Crockett, and Shin (2009)). But while some central banks have made efforts to model the network structure of their national financial systems (e.g. Gai, Haldane, and Kapadia (2011)), the ultimate mechanisms are not so different from models in which feedbacks occur through aggregate quantities and prices: strategic complementarities in risk-taking and/or liquidity demand may lead to multiple equilibria or to inefficiently low activity within a single equilibrium.

\section{Cyclical mechanisms: strategic complementarities over time}

The propagation of financial disturbances across firms and financial institutions naturally generates propagation over time as well. Credit crunches and fire sales persist over time because they leave lower profits in their wake, decreasing the cash and collateral available to support the next round of investment decisions. But other relevant mechanisms are also at work. Crucially, an intertemporal analysis places focus on the contrasting welfare implications associated with ex post and ex ante perspectives on policy responses to financial instability.

\section{Limited commitment}

Existing literature on credit crunches and fire sales mostly takes collateral constraints as given and focuses on ex post policy analysis, asking how to stabilize the financial system and the economy in response to exogenous shocks. But some recent papers dig deeper, using models in which demand for cash and other collateralizable arises endogenously to study whether borrowing in boom times might be excessive, making the economy vulnerable to excessively sharp crashes. Lorenzoni (2008) and Bianchi (2011) present models where ex ante macroprudential policies that reduce borrowing are optimal. In their models, borrowers have a limited ability to commit to future repayments (called nonpledgeability or limited commitment), which makes collateral valuable if additional liquidity is needed before investments pay off. Since firms and households fail to take into account the fire sale externalities that asset liquidation imposes on other investors, their ex ante borrowing level tends to be too high, leading to excessive volatility ex post. Gersbach and Rochet (2012) apply a similar framework to the banking system, incorporating a financial friction that limits banks' borrowing, to study banks' balance sheet decisions. They show that banks allocate too much borrowing capacity to good states of the world (overborrowing) and too little to bad states (underborrowing). This is because banks fail to incorporate the effects of their decisions on the price of capital (a pecuniary externality), implying that this price is too high in good states, increasing bank equity (banks are overcapitalized) and too low in bad states, depressing bank equity (banks become undercapitalized). Hence, these contributions highlight how financial frictions and pecuniary externalities generate cyclical mechanisms that lead to excessive borrowing in booms (which could be offset by macroprudential policy) and excessively deep recessions (which could be offset by macroeconomic stabilization). 
Alternatively, overborrowing and excess volatility can also be explained by departing from rational expectations, to consider different processes for expectation formation. Simply put, over-reliance on recent experience may cause investors to take excessive risks in good times, and to panic and overreact when a downturn hits. On one hand, Gennaioli, Shleifer, and Vishny (2012) and (2015) explain how the dependence of expectations on more frequently seen (salient) states of the world can generate excessive debt issuance and neglect of tail risks. Investors overreact to a series of good news, because such a series is representative of a good state. A few negative announcements will not change their minds because the good state is still representative, but a sufficient amount of bad news leads to a radical change in investors' beliefs and to a financial crisis. Likewise, similar results can also be derived from models of learning - particularly learning about growth rates (rather than levels) of asset prices. Broer and Kero (2011) show that a framework with uncertainty and learning about the persistence of volatility regimes is able to replicate the asset price increases observed during the great moderation (low volatility regime) and its reverse upon the return to the high volatility regime. Gelain, Lansing, and Mendicino (2013) show how learning about the house price process can better explain large fluctuations in house prices, and they explore loan-to-value ratios and other macroprudential policies in a macro model with learning.

\section{Financial cycles}

The cyclical mechanisms discussed above link financial frictions with the business cycle, focusing on amplification of output fluctuations, and how boom times may promote overborrowing via pricing externalities or expectations formation. However, Borio (2014) and Drehmann, Borio, and Tsatsaronis (2012) argue that "financial cycles", identifiable as a fluctuation in financial variables - especially leverage ratios and asset prices - are of lower frequency and greater amplitude than the business cycle itself. Therefore, there may be instances where economic conditions are improving but the financial cycle remains depressed, and even situations where booms and busts coincide. Following Minsky (1986) closely, they associate the boom in financial cycle with the existence of financial imbalances that signal a buildup of risk that may result in a crisis. On the other hand, they also emphasize that the duration and amplitude of financial cycles has varied greatly over time. Thus, even though they show that downturns of the financial cycle are frequently accompanied by financial crises, actually predicting the timing of crises on the basis of this evidence, without further understanding the mechanisms that drive these fluctuations and how they related to output fluctuations, remains exceedingly difficult.

\section{Macroprudential policy - instruments and implementation}

The main macroprudential instruments fall into three main categories: capital, liquidity and credit instruments. Capital-related instruments include flat and countercyclical capital requirements, leverage ratios, and restrictions on profit distribution. Liquidity 
instruments include limits on maturity mismatch and reserve requirements. Credit instruments include caps on loan-to-value (LTV) ratios, caps on debt-to-income (DTI) ratios, leverage ratios, and ceilings on credit or credit growth.

\section{Flat capital requirements}

Capital requirements have long been imposed on the banking sector, although their main purpose has been to guarantee the solvency of individual financial intermediaries instead of mitigating systemic risk. As a result, the current debate has centered on the need to increase capital requirements to avoid the repercussions for the rest of economy when a bank cannot absorb losses due to insufficient equity. Higher regulatory capital requirements force shareholders to increase their exposure to declines in the value of their assets (increasing the "skin in the game"). As such, higher requirements weaken the problems caused by limited liability, including the leverage rachet and risk shifting effects, thus decreasing the likelihood of fire sales, credit crunches, and flights to quality, and they also decrease the degree of asset commonalities in financial intermediation.

\section{Leverage ratio}

Capital requirements are normally set based on the size and composition of assets held by banks, reflecting the underlying risk of the portfolio of assets, often measured in terms of Risk Weighted Assets (RWAs). The risk weights set by the Basel III framework are intended to capture the variability of credit risk exposures across different bank portfolios. However, risk assessment is in many cases based on banks' own internal models, or is based on current pricing. Hence, any deviations in risk perception or pricing due to the structural and cyclical mechanisms discussed above that generate excessive leverage and risk taking, might also lead to a downward bias in capital requirements. Therefore, leverage ratios, which constrain the ratio of assets to capital, are also advocated as an additional instrument to reduce systemic risk. Leverage ratios can be set at the bank level (Basel III) or at the aggregate level (see Gersbach and Hahn (2011)) in association with capital requirements. Leverage ratios directly target the leverage rachet effect, and also affect the key structural propagation mechanisms, as flat capital requirements do. Moreover, given that the biases in risk assessment tend to be procyclical, leverage ratios could also offset limited commitment problems, correcting for the possibility of overborrowing.

\section{Countercyclical capital requirements}

Fixed capital requirements and leverage ratios impact excessive leverage and risk in a time-independent way and thus work primarily against structural propagation mechanisms. Countercyclical capital requirements or buffers, which have recently been introduced in the Basel III framework, are directly aimed at attenuating cyclical mechanisms. The proposed adjustments of those buffers are linked with the medium-term movements in financial cycles; they are currently based on a set of statistical indicators that track financial cycles. The mechanisms that drive financial cycles are remain poorly understood, making it difficult to assess whether the adjustments are inefficiently curbing credit growth or are instead decreasing systemic risk optimally. 


\section{Liquidity ratios and levies}

Maturity mismatch is intrinsic to financial intermediation, since short-term funding is the essence of liquidity provision, but it may also generate negative systemic externalities through fire sales, flight to liquidity, and counterparty risk. Thus, while a bank's decision reflects its own exposure to refinancing risk, it has no incentive to consider its effects on the rest of the financial system, so from a systemic perspective it relies excessively on shortterm funding. This suggests that additional regulation to constrain refinancing exposure to the socially optimal level is needed. This can be done by setting liquidity ratios, as in the new Basel III framework, or levies (Pigouvian taxes) on liquidity exposure (Perotti and Suarez (2011)).

\section{LTV and DTI ratios}

Another set of instruments that addresses excessive leverage and borrowing, but which control market outcomes directly instead of controlling banks' balance sheets, are loanto-value (LTV) and debt-to-income (DTI) ratios. The first looks directly at the housing market, since sharp increases in house prices are strongly associated with the peak of a financial cycle. DTI ratios are more general, and attempt to curb all forms of credit growth. Since these instruments are based on borrowers' asset position, rather than that of the financial institution, they have the advantage that they are effective for controlling excessive credit growth regardless of whether it comes from traditional banks or from the shadow banking system.

\section{Other prudential measures}

A number of other measures and institutional changes have recently been discussed. In order to correct for the limited liability problem without generating excessive deleveraging, regulators have recently introduced restrictions on profit distributions, forcing banks to achieve sufficient capital by retaining more earnings rather than cutting lending. As regards the problems of crisis propagation through the financial system, regulators have recently promoted changes to improve monitoring of banking network structures and have introduced additional balance sheet requirements for systemically important financial institutions to increase their Total Loss Absorbing Capacity (TLAC). This new regulation ensures a better and faster resolution of banking crises, mitigating potential spillovers through the banking network. The need for a framework to oversee payments and securities systems, monitoring over-the-counter markets, has also been receiving some attention in the effort to decrease systemic risk.

Finally, an important aspect of implementation is how discretionary each policy instrument should be. On the one hand, ruled-based policies are predictable, reduce uncertainty, and cannot be modified depending on current pressures or conditions. On the other hand, a discretionary approach allows policymakers to improve their understanding of how macroprudential policies impact the financial markets and the economy, improving policy judgments. As our understanding of the main mechanisms and impacts of policy interventions increases, rule-based interventions should perhaps become the norm, increas- 
ing transparency and accountability. But continuing financial innovation and regulatory arbitrage could justify maintaining some degree of discretion.

\section{Challenges in theory and policy design}

We conclude by looking at major areas where further analysis is warranted, both in terms of theory and of policy design.

\section{Modeling challenges}

The literature on macroprudential policies has advanced considerably in the last few years, particularly in identifying important mechanisms that may generate suboptimal outcomes and may increase the probability of systemic events. Nonetheless, incorporating structural mechanisms that address fire-sales and other corporate governance imperfections in a dynamic setting that allows for persistent effects that quantitatively match observed financial cycles remains a challenge. Hence, a unifying framework that is adequate for analyzing the tradeoffs of macroprudential policies is still lacking. Apart from the general difficulty of incorporating multiple mechanisms into a single framework of financial intermediation, the modeling task might involve dealing with (i) heterogeneity, (ii) multiplicity of equilibrium and (iii) departures from rational expectations.

A rapidly advancing DSGE literature adds financial frictions to standard macroeconomic models. Heterogeneity ought to be explored further here, since collateral constraints and other types of financial frictions are largely irrelevant in representative agent models. Another weakness of this literature is that the dynamics are driven by exogenous shocks. It is still essential to try to derive financial shocks and/or crises from feedbacks in imperfect financial markets, as the policy implications of endogenous fluctuations may differ from those of exogenous shocks. Better frameworks for addressing multiplicity of equilibrium could be helpful in modeling endogenous fluctuations. Finally, although the empirical regularities around financial cycles seemed well documented in, for instance, Drehmann, Borio, and Tsatsaronis (2012), the mechanisms that drive financial variables and differentiate financial cycles from the more familiar output cycles remain elusive. Models of learning may prove crucial for modeling the financial cycle; Minsky's (1986) theory suggests that innovations in the recent past are salient for investment behavior, and plausible calibrations of learning models often imply fluctuations of much lower frequency than rational expectations models do.

Two recent papers have addressed some of these concerns, providing general equilibrium frameworks for studying financial instability and policy interventions. Boissay, Collard, and Smets (forthcoming) build a tractable DSGE model with an interbank market in which moral hazard and asymmetric information may generate banking crises, credit crunches, and ultimately a severe financial recession. In accordance with the empirical evidence these recessions are infrequent, are more likely to occur following a credit boom, and are not triggered by an especially large negative exogenous shock. Brunnermeier and Sannikov (2014) study a more stylized general equilibrium model in which collateral constraints cause asset prices to vary with the fraction of total wealth held by entrepreneurs. Rather than analyzing fluctuations around a single steady state, the authors describe the full, global dynamics of their economy, and show that it tends to fluctuate around two 
persistent states, a "normal" situation in which risk has only a small effect on asset prices, and a "crisis" state in which investment is reduced by a high risk premium, which can only be escaped through a slow process of deleveraging. A key source of risk for entrepreneurs in their model is the endogenous riskiness of the price of capital. An important finding is that price volatility may increase when the variance of exogenous shocks falls. That is, less exogenous risk (or improved diversification through financial innovation) may cause entrepreneurs to leverage up in normal times, increasing the endogenous component of risk and making crises, when they arrive, more severe. ${ }^{5}$

\section{Challenges for effective regulation}

Major challenges for effective regulation include determining the appropriate size and type of interventions, and anticipating potential side-effects both within and across sectors. Firstly, given the lack of a widely-accepted macroeconomic model that encompasses financial crises and macroprudential policy, quantitative analyses are still lacking. For instance, the appropriate level of capital requirements is hotly contested. Admati, DeMarzo, Hellwig, and Pfleiderer (2013a) discuss a series of misconceptions regarding banking capital (e.g. "equity is expensive", "capital implies banks set aside resources that are not used restricting lending") and claim that higher capital, as required by the new Basel III framework, entails large social benefits at minimal or no social cost. De Nicolo, Gamba, and Lucchetta (2012) argue that even if capital requirements are initially beneficial, there is a point where further increases become costly, reducing lending, efficiency, and welfare. Note that this conclusion hinges on the restrictions to equity issuance assumed in their framework. Another relevant consideration is whether regulation should focus on prices or quantities. Perotti and Suarez (2011) discuss this issue in the context of policy to control liquidity exposure. They show that quantity constraints are preferred when risk taking incentives are heterogenous across banks, while levies are preferred when heterogeneity is on the capacity to generate gains in intermediation (bank quality); therefore a combination of instruments might be optimal in general. Finally, adjustments to countercyclical capital buffers are at present largely discretionary, loosely based on a set of indicators that have proven to correlate to booms in financial cycles.

Regulatory interventions can have important side-effects and potential leakages. For instance, countercyclical capital requirements are set to control increases in systemic risk during periods of positive credit and asset price growth. However, as Horvath and Wagner (2013) show, countercyclical capital requirements also create incentives to invest in correlated activities, as it is relatively more costly to be forced to re-capitalize in booms. This may lead to higher degree of asset commonality, which increases systemic risk. As for potential side-effects, Aiyar, Calomiris, and Wieladek (2014) show that after an increase in capital requirements in the UK, regulated banks do decrease credit supply. However, unregulated banks (resident foreign branches) increase lending in response to tighter capital requirements on a relevant reference group of regulated banks. Thus, they observe a leakage within the banking sector. An important question requiring further exploration is how macroprudential policies aimed at the banking sector affect other financial intermediaries,

\footnotetext{
${ }^{5}$ The paper of Brunnermeier and Sannikov (2014) also illustrates the techical advantages of moving from traditional discrete-time macroeconomic models to continuous-time modeling, which may prove more tractable for nonlinear analysis of economies with financial frictions.
} 
and what role these might play in generating externalities and increasing systemic risk. Further constraints on commercial banks are likely to increase the importance of shadow banks, which were already the entities responsible for most of the increased leverage observed during the pre-crisis period. Adrian (2014) discusses regulatory policies directed towards shadow banks. His proposal highlights the need to shift the regulatory instruments from institutions to types of transactions (for example, LTV ratios are regulations that shift the focus from banks' balance sheets to requirements on mortgage contracts). Finally, non-leveraged investors like hedge funds, who are motivated by relative performance ranking, might exacerbate asset price volatility (Feroli, Kashyap, Schoenholtz, and Shin (2014)).

\section{Monetary and macroprudential policy}

Monetary and macroprudential policies are clearly linked. By setting short-term interest rates, monetary policy affects credit and interest rate spreads, and thus influences (future) financial stability. Macroprudential policy, by curbing excessive leverage and risk taking, influences the terms and conditions of credit, and thereby the real economy and the rate of inflation. A recurring question is whether some degree of coordination is needed in this reciprocal relationship, recognizing that monetary policy has a role to play in financial stability, or whether these policies can instead by conducted largely independently.

The pro-independence view claims that $(i)$ interest rates are not an adequate instrument to control financial stability and as such leaning against the wind cannot solve debt problems (Svensson (2014)); (ii) even if monetary policy is effective in influencing financial stability, monetary policymaking should ignore it since otherwise the goal of controlling inflation effectively would be undermined (Weidmann (2014)); and (iii) if macroprudential regulations are found to deal appropriately with all relevant externalities, there would be no need for monetary policy to focus on issues of systemic risk.

The pro-collaboration view stresses that monetary policy affects financial stability mostly through incentives to take risk. Prolonged periods of low interest rates may lead investors to "search for yield", promoting credit issuance, reducing premia and increasing asset prices (Borio and Zhu (2008), Morris and Shin (2014)). This mechanism might be important to understand the dynamics of financial cycles and hence, monetary policy should also incorporate financial stability objectives, at least in the expansionary phase of the cycle (see Stein (2011) and Borio and White (2003)).

Ajello, Laubach, Lopez-Salido, and Nakata (2015) build a framework that attempts to quantify the potential tradeoffs for monetary policy-making when financial stability is a concern; they assume that the probability of crisis varies with credit and thus with the interest rate. They show that the optimal adjustment of interest rates due to stability concerns is generally small but may be higher if the central bank is uncertain about how interest rates affect financial stability. The crucial element then is to analyze how interest rate movements and the probability of a crisis are linked. Given that financial cycles seem to be of lower frequency, this might be related to interest rate persistence, which is not explored in their model. Moreover, using interest rates to decrease the stock of debt is not straightforward: tighter policy may reduce inflation and disposable income more quickly than the stock of debt, thereby increasing real debt and the debt-to-income ratio. Hence, using prudential instruments to influence the probability of a crisis might be more efficient. 


\begin{tabular}{ll}
\hline \hline & \multicolumn{1}{c}{ Micro Perspective } \\
\hline Excessive Leverage & Admati, DeMarzo, Hellwig, and Pfleiderer (2013b) \\
Risk Shifting & Kashyap, Rajan, and Stein (2002) \\
& Jensen and Meckling (1976) \\
Maturity Mismatch & Bolton, Mehran, and Shapiro (2010) \\
& Diamond and Dybvig (1983) \\
& Brunnermeier and Oehmke (2013) \\
\hline \hline & Macro Perspective - Cross Section \\
\hline Fire Sales/ Credit Crunch & Allen and Gale (2004) \\
& Bernanke, Gertler, and Gilchrist (1999) \\
& Allen and Gale (1994) \\
& Kiyotaki and Moore (1997) \\
& Brunnermeier and Pedersen (2009) \\
Asset Commonalities & Acharya (2009) \\
& Allen, Babus, and Carletti (2012) \\
System Propagation & Allen and Gale (2000) \\
& Brunnermeier, Goodhart, Persaud, Crockett, and Shin \\
& (2009) \\
\hline \hline & Macro Perspective - Cyclical \\
\hline Limited Commitment & Lorenzoni (2008) \\
Information flow and Learning & Gersbach and Rochet (2012) \\
& Gennaioli, Shleifer, and Vishny (2012) \\
Financial Cycles & Broer and Kero (2011) \\
\hline \hline & Drehmann, Borio, and Tsatsaronis (2012) \\
\hline
\end{tabular}


Table 2: Instruments and Mechanisms

\begin{tabular}{|c|c|c|}
\hline Instrument & Cross-Section Propagation & Cyclical Mechanisms \\
\hline $\begin{array}{l}\text { Flat Capital Requirement } \\
\text { (CR) }\end{array}$ & $\begin{array}{l}\uparrow \text { CR increases skin in the game } \\
\Rightarrow \downarrow \text { risk taking and } \downarrow \text { leverage } \\
\Rightarrow \downarrow \text { probability of fire sales, credit } \\
\text { crunches and } \downarrow \text { asset commonalities } \\
\text { across banks. }\end{array}$ & \\
\hline $\begin{array}{ll}\text { Countercyclical } & \text { Capital } \\
\text { Requirements } & \end{array}$ & & $\begin{array}{l}\text { Increased CR in booms } \\
\Rightarrow \downarrow \text { less lending in booms } \\
\Rightarrow \quad \downarrow \text { subsequent downturn less } \\
\text { severe. }\end{array}$ \\
\hline Leverage Ratios (LvR) & $\begin{array}{l}\text { Quantity control on balance sheets } \\
\Rightarrow \downarrow \text { leverage } \Rightarrow \downarrow \text { probability of fire } \\
\text { sales, credit crunches. }\end{array}$ & $\begin{array}{l}\text { Quantity controls independent of } \\
\text { market prices and risk perceptions, } \\
\text { which tend to be pro-cyclical. Hence } \\
\text { LvR } \Rightarrow \downarrow \text { ex-ante overborrowing }\end{array}$ \\
\hline $\begin{array}{l}\text { Liquidity Ratios and } \\
\text { Levies }\end{array}$ & $\begin{array}{l}\text { Quantity controls and tax on short- } \\
\text { term financing } \\
\Rightarrow \downarrow \text { maturity mismatch } \\
\Rightarrow \downarrow \text { likelihood of fire sales and flight } \\
\text { to liquidity }\end{array}$ & \\
\hline LTV and DTI & $\begin{array}{l}\text { Quantity constraint: } \\
\text { leverage } \downarrow \\
\text { Quantity constraint: corporate } \\
\text { leverage } \downarrow \\
\Rightarrow \downarrow \text { likelihood of fire sales and } \\
\text { credit crunches. }\end{array}$ & $\begin{array}{l}\text { Borrowing reduced on average, but } \\
\text { values and income are procyclical } \\
\Rightarrow \text { LTV and DTI might be ineffect- } \\
\text { ive against cyclical mechanisms. }\end{array}$ \\
\hline $\begin{array}{l}\text { Other Instruments } \\
\text { TLAC } \\
\text { Monitoring of networks } \\
\text { and payment systems }\end{array}$ & $\begin{array}{l}\text { improve bankruptcy resolution } \\
\Rightarrow \text { avoid crisis propagation } \\
\Rightarrow \text { avoid crisis propagation }\end{array}$ & \\
\hline
\end{tabular}




\section{References}

Acharya, V. V. (2009): "A theory of systemic risk and design of prudential bank regulation," Journal of Financial Stability, 5(3), 224-255.

Admati, A. R., P. M. Demarzo, M. F. Hellwig, and P. Pfleiderer (2013a): "Fallacies, Irrelevant Facts, and Myths in the Discussion of Capital Regulation: Why Bank Equity is Not Socially Expensive," Working Paper Series of the Max Planck Institute for Research on Collective Goods 2013_23, Max Planck Institute for Research on Collective Goods.

(2013b): "The Leverage Ratchet Effect," Working paper series of the max planck institute for research on collective goods, Max Planck Institute for Research on Collective Goods.

Adrian, T. (2014): "Financial stability policies for shadow banking," Staff Reports 664, Federal Reserve Bank of New York.

Aiyar, S., C. W. Calomiris, and T. Wieladek (2014): "Does Macro-Prudential Regulation Leak? Evidence from a UK Policy Experiment," Journal of Money, Credit and Banking, 46(s1), 181-214.

Ajello, A., T. Laubach, D. Lopez-Salido, and T. Nakata (2015): "Financial Stability and Optimal Interest-Rate Policy," mimeo, Federal Reserve Board.

Allen, F., A. Babus, and E. Carletti (2012): "Asset commonality, debt maturity and systemic risk," Journal of Financial Economics, 104(3), 519-534.

Allen, F., And D. Gale (1994): "Limited Market Participation and Volatility of Asset Prices," American Economic Review, 84(4), 933-55.

(2000): "Financial Contagion," Journal of Political Economy, 108(1), 1-33.

(2004): "Competition and Financial Stability," Journal of Money, Credit and Banking, 36(3), 453-80.

Bernanke, B. S., M. Gertler, and S. Gilchrist (1999): "The financial accelerator in a quantitative business cycle framework," in Handbook of Macroeconomics, ed. by J. B. Taylor, and M. Woodford, vol. 1, chap. 21, pp. 1341-1393. Elsevier.

BiAnCHI, J. (2011): "Overborrowing and Systemic Externalities in the Business Cycle," American Economic Review, 101(7), 3400-3426.

Boissay, F., F. Collard, and F. Smets (forthcoming): "Booms and banking crises," Journal of Politial Economy.

Bolton, P., H. Mehran, and J. Shapiro (2010): "Executive compensation and risk taking," Discussion paper.

Borio, C. (2014): "The financial cycle and macroeconomics: What have we learnt?," Journal of Banking \& Finance, 45(C), 182-198. 
Borio, C., And W. R. White (2003): "Whither monetary and financial stability : the implications of evolving policy regimes," Proceedings - Economic Policy Symposium Jackson Hole, pp. 131-211.

Borio, C., AND H. ZHU (2008): "Capital regulation, risk-taking and monetary policy: a missing link in the transmission mechanism?," BIS Working Papers 268, Bank for International Settlements.

Broer, T., And A. Kero (2011): "Great Moderation or Great Mistake: Can rising confidence in low macro-risk explain the boom in asset prices?," CEPR Discussion Papers 8700, C.E.P.R. Discussion Papers.

Brunnermeier, M. K., C. A. E. Goodhart, A. Persaud, A. Crockett, and H. SHIN (2009): The fundamental principles of financial regulation. International Center for Monetary and Banking Studies ; Centre for Economic Policy Research.

Brunnermeier, M. K., And M. Oehmke (2013): "The Maturity Rat Race," Journal of Finance, 68(2), 483-521.

Brunnermeier, M. K., and L. H. Pedersen (2009): "Market Liquidity and Funding Liquidity," Review of Financial Studies, 22(6), 2201-2238.

Brunnermeier, M. K., And Y. Sannikov (2014): "A Macroeconomic Model with a Financial Sector," American Economic Review, 104(2), 379-421.

Calomiris, C. W., and C. M. Kahn (1991): "The Role of Demandable Debt in Structuring Optimal Banking Arrangements," American Economic Review, 81(3), 497-513.

De Nicolo, G., A. Gamba, and M. Lucchetta (2012): "Capital Regulation, Liquidity Requirements and Taxation in a Dynamic Model of Banking," IMF Working Papers 12/72, International Monetary Fund.

Diamond, D. W., And P. H. Dybvig (1983): "Bank Runs, Deposit Insurance, and Liquidity," Journal of Political Economy, 91(3), 401-19.

Drehmann, M., C. Borio, and K. Tsatsaronis (2012): "Characterising the financial cycle: don't lose sight of the medium term!," BIS Working Papers 380, Bank for International Settlements.

Farhi, E., And J. Tirole (2012): "Collective Moral Hazard, Maturity Mismatch, and Systemic Bailouts," American Economic Review, 102(1), 60-93.

Feroli, M., A. K. Kashyap, K. L. Schoenholtz, and H. S. Shin (2014): "Market Tantrums and Monetary Policy," Chicago booth research paper, Chicago Booth.

Gai, P., A. Haldane, and S. Kapadia (2011): "Complexity, concentration and contagion," Journal of Monetary Economics, 58(5), 453-470.

Garleanu, N., and L. H. Pedersen (2007): "Liquidity and Risk Management," American Economic Review, 97(2), 193-197. 
Gelain, P., K. J. Lansing, and C. Mendicino (2013): "House Prices, Credit Growth, and Excess Volatility: Implications for Monetary and Macroprudential Policy," International Journal of Central Banking, 9(2), 219-276.

Gennaioli, N., A. Shleifer, and R. Vishny (2012): "Neglected risks, financial innovation, and financial fragility," Journal of Financial Economics, 104(3), 452-468.

(2015): "Neglected Risks: The Psychology of Financial Crises," NBER Working Papers 20875, National Bureau of Economic Research, Inc.

Gersbach, H., and V. Hahn (2011): "Modeling Two Macro Policy Instruments - Interest Rates and Aggregate Capital Requirements," CESifo Working Paper Series 3598, CESifo Group Munich.

Gersbach, H., and J.-C. Rochet (2012): "Capital Regulation and Credit Fluctuations," Discussion paper.

Gertler, M., and N. Kiyotaki (2010): "Financial Intermediation and Credit Policy in Business Cycle Analysis," in Handbook of Monetary Economics, ed. by B. M. Friedman, and M. Woodford, vol. 3, chap. 11, pp. 547-599. Elsevier.

Goodhart, C. A., A. K. Kashyap, D. P. Tsomocos, and A. P. Vardoulakis (2012): "Financial Regulation in General Equilibrium," NBER Working Papers 17909, National Bureau of Economic Research, Inc.

Goodhart, C. A., And E. Perotti (2015): "Maturity mismatch stretching: Banking has taken a wrong turn," CEPR Policy Insight 81, Centre for Economic Policy Research.

Hanson, S. G., A. K. Kashyap, and J. C. Stein (2011): "A Macroprudential Approach to Financial Regulation," Journal of Economic Perspectives, 25(1), 3-28.

Holmstrom, B., and J. Tirole (1997): "Financial Intermediation, Loanable Funds, and the Real Sector," Quarterly Journal of Economics, 112(3), 663-91.

Horvath, B., And W. Wagner (2013): "The Disturbing Interaction between Countercyclical Capital Requirements and Systemic Risk," Working paper, Tilburg University, Center for Economic Research.

Huang, R., And L. Ratnovski (2011): "The dark side of bank wholesale funding," Journal of Financial Intermediation, 20(2), 248-263.

Jensen, M. C., And W. H. Meckling (1976): "Theory of the firm: Managerial behavior, agency costs and ownership structure," Journal of Financial Economics, 3(4), 305-360.

Kashyap, A. K., R. Rajan, and J. C. Stein (2002): "Banks as Liquidity Providers: An Explanation for the Coexistence of Lending and Deposit-Taking," Journal of Finance, 57(1), 33-73.

Kiyotaki, N., and J. Moore (1997): "Credit Cycles," Journal of Political Economy, $105(2), 211-48$. 
Lorenzoni, G. (2008): "Inefficient Credit Booms," Review of Economic Studies, 75(3), 809-833.

Manconi, A., M. Massa, and A. Yasuda (2012): "The role of institutional investors in propagating the crisis of 20072008," Journal of Financial Economics, 104(3), 491-518.

Mencía, J., And J. SAurina (2016): "Macroprudential Policy: Objectives, Instruments and Indicators," Occasional Papers 2016, Banco de España.

Minsky, H. (1986): Stabilizing an Unstable Economy. Yale University Press, New Haven and London.

Modigliani, F., And M. H. Miller (1958): "The Cost of Capital, Corporation Finance and the Theory of Investment," The American Economic Review, 48(3), 261-297.

Morris, S., And H. S. Shin (2014): "Risk-Taking Channel of Monetary Policy: A Global Game Approach," Working papers, Princeton University.

Perotti, E., And J. Suarez (2011): "A Pigovian Approach to Liquidity Regulation," International Journal of Central Banking, 7(4), 3-41.

Rajan, R. G. (1994): "Why Bank Credit Policies Fluctuate: A Theory and Some Evidence," The Quarterly Journal of Economics, 109(2), 399-441.

REPullo, R. (2004): "Capital requirements, market power, and risk-taking in banking," Journal of Financial Intermediation, 13(2), 156-182.

Rochet, J.-C., And J. Tirole (1996): "Interbank Lending and Systemic Risk," Journal of Money, Credit and Banking, 28(4), 733-62.

Stein, J. C. (2011): "Monetary Policy as Financial-Stability Regulation," Nber working papers, National Bureau of Economic Research, Inc.

Svensson, L. (2014): "Monetary policy trade-offs in CESEE," Conference on european economic integration (ceei) 2014, Viena, 24 November.

Wagner, W. (2010): "Diversification at financial institutions and systemic crises," Journal of Financial Intermediation, 19(3), 373-386.

Weidmann, J. (2014): "All for one and one for all? The roles of microprudential, macroprudential, and monetary policy in safeguarding financial stability," Frankfurt, 27 february, Speech at the Bundesbank Symposium on Financial Stability and the Role of Central Banks,. 


\title{
BANCO DE ESPAÑA PUBLICATIONS
}

\author{
OCCASIONAL PAPERS
}

0701 JOSÉ LUIS MALO DE MOLINA: Los principales rasgos y experiencias de la integración de la economía española en la UEM.

0702 ISABEL ARGIMÓN, FRANCISCO DE CASTRO and ÁNGEL LUIS GÓMEZ: Una simulación de los efectos de la reforma del IRPF sobre la carga impositiva.

0703 YENER ALTUNBAŞ, ALPER KARA and ADRIAN VAN RIXTEL: Corporate governance and corporate ownership: The investment behaviour of Japanese institutional investors.

0704 ARTURO MACÍAS and ÁLVARO NASH: Efectos de valoración en la posición de inversión internacional de España.

0705 JUAN ÁNGEL GARCÍA and ADRIAN VAN RIXTEL: Inflation-linked bonds from a central bank perspective.

0706 JAVIER JAREÑO: Las encuestas de opinión en el análisis coyuntural de la economía española.

0801 MARÍA J. NIETO and GARRY J. SCHINASI: EU framework for safeguarding financial stability: Towards an analytical benchmark for assessing its effectiveness,

0802 SILVIA IRANZO: Delving into country risk. (There is a Spanish version of this edition with the same number).

0803 OLYMPIA BOVER: The Spanish survey of household finances (EFF): Description and methods of the 2005 wave.

0804 JAVIER DÍAZ-CASSOU, AITOR ERCE-DOMÍNGUEZ and JUAN J. VÁZQUEZ-ZAMORA: Recent episodes of sovereign debt restructurings. A case-study approach.

0805 JAVIER DÍAZ-CASSOU, AITOR ERCE-DOMIINGUEZ and JUAN J. VÁZQUEZ-ZAMORA: The role of the IMF in recent sovereign debt restructurings: Implications for the policy of lending into arrears.

0806 MIGUEL DE LAS CASAS and XAVIER SERRA: Simplification of IMF lending. Why not just one flexible credit facility?

0807 MIGUEL GARCÍA-POSADA and JOSEP M. ${ }^{a}$ VILARRUBIA: Mapa de exposición internacional de la economía española.

0808 SARAI CRIADO and ADRIAN VAN RIXTEL: Structured finance and the financial turmoil of 2007-2008: An introductory overview. (There is a Spanish version of this edition with the same number).

0809 FRANCISCO DE CASTRO and JOSÉ M. GONZÁLEZ-MÍNGUUEZ: La composición de las finanzas públicas y el crecimiento a largo plazo: Un enfoque macroeconómico.

0810 OLYMPIA BOVER: The dynamics of household income and wealth: results from the panel of the Spanish survey of household finances (EFF) 2002-2005. (There is a Spanish version of this edition with the same number).

0901 ÁNGEL ESTRADA, JUAN F. JIMENO and JOSÉ LUIS MALO DE MOLINA: The Spanish economy in EMU: the first ten years. (There is a Spanish version of this edition with the same number).

0902 ÁNGEL ESTRADA and PABLO HERNÁNDEZ DE COS: Oil prices and their effect on potential output. (There is a Spanish version of this edition with the same number).

0903 PALOMA LÓPEZ-GARCÍA, SERGIO PUENTE and ÁNGEL LUIS GÓMEZ: Employment generation by small firms in Spain.

0904 LUIS J. ÁLVAREZ, SAMUEL HURTADO, ISABEL SÁNCHEZ and CARLOS THOMAS: The impact of oil price changes on Spanish and euro area consumer price inflation.

0905 CORAL GARCÍA, ESTHER GORDO, JAIME MARTÍNEZ-MARTÍN and PATRY TELLO: Una actualización de las funciones de exportación e imporción de la economía española.

1001 L. J. ÁLVAREZ, G. BULLIGAN, A. CABRERO, L. FERRARA and H. STAHL: Housing cycles in the major euro area countries.

1002 SONSOLES GALLEGO, SÁNDOR GARDÓ, REINER MARTIN, LUIS MOLINA and JOSÉ MARÍA SERENA: The impact of the global economic and financial crisis on Central Eastern and SouthEastern Europe (CESEE) and Latin America.

1101 LUIS ORGAZ, LUIS MOLINA and CARMEN CARRASCO: El creciente peso de las economías emergentes en la economía y gobernanza mundiales. Los países BRIC.

1102 KLAUS SCHMIDT-HEBBEL: Central banking in Latin America: changes, achievements, challenges. (There is a Spanish version of this edition with the same number).

1103 OLYMPIA BOVER: The Spanish Survey of Household Finances (EFF): description and methods of the 2008 wave.

1104 PABLO HERNÁNDEZ DE COS, MARIO IZQUIERDO and ALBERTO URTASUN: An estimate of the potential growth of the Spanish economy. (There is a Spanish version of this edition with the same number).

1105 ENRIQUE ALBEROLA, CARLOS TRUCHARTE and JUAN LUIS VEGA: Central banks and macroprudential policy. Some reflections from the Spanish experience.

1106 SAMUEL HURTADO, ELENA FERNÁNDEZ, EVA ORTEGA and ALBERTO URTASUN: Nueva actualización del modelo trimestral del Banco de España.

1107 PABLO HERNÁNDEZ DE COS and ENRIQUE MORAL-BENITO: Health care expenditure in the OECD countries: efficiency and regulation. (There is a Spanish version of this edition with the same number). 
1201 ELOÍSA ORTEGA and JUAN PEÑALOSA: The Spanish economic crisis: key factors and growth challenges in the euro area. (There is a Spanish version of this edition with the same number).

1202 MARÍA J. NIETO: What role, if any, can market discipline play in supporting macroprudential policy?

1203 CONCHA ARTOLA and ENRIQUE GALÁN: Tracking the future on the web: construction of leading indicators using internet searches. (There is a Spanish version of this edition with the same number).

1204 JOSÉ LUIS MALO DE MOLINA: Luis Ángel Rojo en el Banco de España.

1205 PABLO HERNÁNDEZ DE COS and CARLOS THOMAS: El impacto de la consolidación fiscal sobre el crecimiento económico. Una ilustración para la economía española a partir de un modelo de equilibrio general.

1206 GALO NUÑO, CRISTINA PULIDO and RUBÉN SEGURA-CAYUELA: Long-run growth and demographic prospects in advanced economies.

1207 IGNACIO HERNANDO, JIMENA LLOPIS and JAVIER VALLÉS: Los retos para la política económica en un entorno de tipos de interés próximos a cero.

1208 JUAN CARLOS BERGANZA: Fiscal rules in Latin America: a survey.

1209 ÁNGEL ESTRADA and EVA VALDEOLIVAS: The fall of the labour income share in advanced economies.

1301 ETTORE DORRUCCI, GABOR PULA and DANIEL SANTABÁRBARA: China's economic growth and rebalancing.

1302 DANIEL GARROTE, JIMENA LLOPIS and JAVIER VALLÉS: Los canales del desapalancamiento del sector privado: una comparación internacional.

1303 PABLO HERNÁNDEZ DE COS and JUAN F. JIMENO: Fiscal policy and external imbalances in a debt crisis: the Spanish case.

1304 ELOÍSA ORTEGA and JUAN PEÑALOSA: Algunas reflexiones sobre la economía española tras cinco años de crisis.

1401 JOSÉ MARÍA SERENA and EVA VALDEOLIVAS: Integración financiera y modelos de financiación de los bancos globales.

1402 ANTONIO MONTESINOS, JAVIER J. PÉREZ and ROBERTO RAMOS: El empleo de las Administraciones Públicas en España: caracterización y evolución durante la crisis.

1403 SAMUEL HURTADO, PABLO MANZANO, EVA ORTEGA and ALBERTO URTASUN: Update and re-estimation of the Quarterly Model of Banco de España (MTBE).

1404 JUAN CARLOS BERGANZA, IGNACIO HERNANDO and JAVIER VALLÉS: Los desafíos para la política monetaria en las economías avanzadas tras la Gran Recesión.

1405 FERNANDO LÓPEZ VICENTE and JOSÉ MARÍA SERENA GARRALDA: Macroeconomic policy in Brazil: inflation targeting, public debt structure and credit policies.

1406 PABLO HERNÁNDEZ DE COS and DAVID LÓPEZ RODRÍGUEZ: Tax structure and revenue-raising capacity in Spain: A comparative analysis with the UE. (There is a Spanish version of this edition with the same number).

1407 OLYMPIA BOVER, ENRIQUE CORONADO and PILAR VELILLA: The Spanish survey of household finances (EFF): description and methods of the 2011 wave.

1501 MAR DELGADO TÉLLEZ, PABLO HERNÁNDEZ DE COS, SAMUEL HURTADO and JAVIER J. PÉREZ: Extraordinary mechanisms for payment of General Government suppliers in Spain. (There is a Spanish version of this edition with the same number).

1502 JOSÉ MANUEL MONTERO y ANA REGIL: La tasa de actividad en España: resistencia cíclica, determinantes y perspectivas futuras.

1503 MARIO IZQUIERDO and JUAN FRANCISCO JIMENO: Employment, wage and price reactions to the crisis in Spain: Firm-level evidence from the WDN survey.

1504 MARÍA DE LOS LLANOS MATEA: La demanda potencial de vivienda principal.

1601 JESÚS SAURINA and FRANCISCO JAVIER MENCÍA: Macroprudential policy: objectives, instruments and indicators. (There is a Spanish version of this edition with the same number).

1602 LUIS MOLINA, ESTHER LÓPEZ y ENRIQUE ALBEROLA: El posicionamiento exterior de la economía española.

1603 PILAR CUADRADO and ENRIQUE MORAL-BENITO: Potential growth of the Spanish economy. (There is a Spanish version of this edition with the same number).

1604 HENRIQUE S. BASSO and JAMES COSTAIN: Macroprudential theory: advances and challenges.

\section{BANCODEESPAÑA}

Eurosistema
Unidad de Servicios Auxiliares

Alcalá, 48 - 28014 Madrid

E-mail: publicaciones@bde.es www.bde.es 